\title{
Assessment of the Competitiveness and economic development policies of the countries of the Former French Empire
}

\author{
Mikhail Savelyev ${ }^{1}$, Tatiana Gruzdeva $^{2}$, Andrey Savchenko ${ }^{1}$, Vladimir Koretsky ${ }^{2}$, and \\ Natalia Pushina ${ }^{2}$ \\ ${ }^{1}$ Mitra Association, Pushkinskaya Str. 241, 60, 426008 Izhevsk, Russia \\ ${ }^{2}$ FSBEI HE M.T. Kalashnikov IzhSTU, Studencheskaya Str. 7, 426069 Izhevsk, Russia
}

\begin{abstract}
A methodology for assessing the competitiveness and policy of economic development of the countries has been developed. As an indicator of competitiveness, the advanced development index is proposed, defined as the ratio of the growth rate of a country's real GDP to the global indicator. To assess the policy of economic development, it is proposed to use an assessment of changes in the advanced development index and the standard deviation of the annual growth rates of real GDP, evaluated for the periods of economic cycles from the beginning of the recovery to the end of the recession, in comparison with the previous period. The second indicator is proposed to be used as an indicator of the sustainability of economic growth and development risk. Such an assessment tool allows four types of economic development policies to be defined including conservative, aggressive, progressive, and regressive ones, when, in comparison with the previous period, the advanced development index and the growth sustainability indicator, respectively, fall or grow in the next period. On the basis of these indicators, an evaluation of the index of the proximity of historical fate is proposed. The developed methodology is applied to the assessment of the economic development of the countries of the former French Empire since 1952. The analysis of the indicators made it possible to reveal that the similarity of the economic development of countries that were previously part of the same empire, the higher, the closer the cultures of these countries, and the further away, the further away from their cultures. At the same time, only those countries achieved advanced development that, after gaining independence, which were able to form their own institutional system, significantly different from the colonial institutions of the metropolis. No signs of the emergence of French civilization, united by a common historical destiny, have been found on the territory of the former French Empire. The obtained scientific result is proof of the need to develop a model of a multipolar world, in which it is necessary to include a provision on the need to form institutions of economic development that are authentic to each culture.
\end{abstract}




\section{Introduction}

The study of the economic development of countries with different cultures, but previously included in the same State entity, allows the impact of institutions from the impact of culture to be distinguished. In this kind of research, it is possible to put forward a few hypotheses:

- the higher cultural commonalities between countries that previously were parts of the same State entity the more similar their economic development;

- in different cultures, the most effective development appears under different institutional models.

These hypotheses were theoretically substantiated in our previous studies, which showed the relationship between culture and institutional models [1-4].

Confirmation or refutation of these hypotheses is possible on data from countries that were previously part of the French Empire, especially since the third of the French empires collapsed at a time when data on economic development were sufficiently reliable. In the sample, we included, in addition to France, Canada and Haiti (royal empire), Switzerland (Napoleonic empire), and a group of countries of the third empire: Syria, Algeria, Vietnam and African colonies. At the same time, data from West African and Central African countries are considered together as two separate research objects. The group of West African countries comprises the former colonies of France: Benin, Burkina Faso, Guinea, Mauritania, Mali, Niger, Senegal, Togo. In the group of Central African countries are included Cameroon, Gabon, Congo, Central African Republic, Chad, as well as Frenchspeaking Rwanda, Burundi and Equatorial Guinea, which were colonies of Belgium and Spain. The modern development of African countries is associated with their grouping into unions and communities in accordance with territorial division, within which a unified regulation of economic activity is ensured [5].

The economic development of the country is influenced not only by the social and political, but also by the cultural development of the country's population. The development models of Switzerland and Canada are interesting because they political independence from France was obtained relatively long ago from the analyzed period, in the 19th and 18th centuries, respectively, and the economies of these countries are generally recognized as developed. Haiti, despite the fact that it was freed from the influence of France in the 19th century, is the poorest country in the world. The countries of Asia and Africa gained independence only in the second half of the 20th century and therefore, periods of dependent and independent economic management were included in the base of this study.

Some classical works focus on the history of the French economy [6-9]. The economic development of France in the period 1944-1973 and the role of dirigisme in this period are described by Khudokormov A.G. [10]. The work [11] is devoted to the analysis of the experience of forming long-term development strategies in Canada. The work [12] is concentrated on changes in the priorities of the economic policy of the governments of Canada.

\section{Materials and Methods}

The subject of the research is the difference in the economic development of the studied countries. Statistical data on the dynamics of the gross domestic product (hereinafter referred to as GDP) for the period from 1952 to 2018 were used as feedstock for the study. The indicator of the adjusted growth rate was used as an indicator of the dynamics of GDP (the growth rate of the country's real GDP in relation to the growth rate of the world economy) - advanced development index, in order to be able to compare the development of countries in different periods. 
The study periods were determined by the dynamics of France's GDP: 1953-1959, 1960-1968, 1969-1975, 1976-1985, 1986-1993, 1994-2001, 2002-2010, 2011-2018. The boundaries of these cycles are from the first year of the beginning of economic growth in GDP to the last year of recession or slowdown. In this paper, a limited number of economic cycles have been analyzed due to the lack of statistical data on the former colonies for previous years. The indicators of the dynamics of real GDP were analyzed. The data sources were Angus Maddison Historical Statistics [13, 14], Total economy database [15], and World Bank [16]. Based on these data, for each period, in addition to the advanced development index, the indicator of growth stability (development risk) was calculated aka the standard deviation of the annual growth rates of real GDP.

If the subsequent period compared to the previous one has a lower risk indicator and a higher growth rate, then such changes in economic development can be considered progressive, the reverse change - regressive. If risks and growth are falling, then such development can be considered conservative, and if they grow, aggressive. If the growth rate of the country's GDP is higher than the world one (their ratio in the figures is more than 1), then such development can be considered outstripping, otherwise we observe a lag in development.

\section{Research Results, Discussion}

The results of the analysis of data on the growth and stability of GDP growth in the studied countries are presented in Fig. 1. In France, in addition to the period 1960-68, we observe a lag in development from global growth. It was this single period of advanced development (de Gaulle's presidency) that was progressive in comparison with the previous period. This was followed by regressive (1969-75, 2002-10), conservative (1976-85, 1994-2001) and aggressive (1986-93) periods. Taking into account that the period 2011-18 is incomplete the crisis came only in 2020 , then the last period is likely to be conservative.

Switzerland for all periods of observation shows a lag in economic development relative to the world. Its progressive development falls on the period 1976-85 and the next 1986-93. These phases followed the regressive period of 1969-75. Most of the periods can be characterized as conservative (1960-68, 1994-2001, 2011-18). The aggressive period of development falls on 2002-2010. There are 2 out of 6 studied periods coincidence of development policies with France (see Table 1) and one opposite development trend (20022010).

Acceleration of Canada relates to three periods: progressive (1960-68 and 1994-2001) and aggressive (1969-75). The lag in development from the world economy is associated with conservative (1986-93, 2011-18) and regressive development (1976-85, 2002-10). The number of coincident and opposite trends is also 2 and 1.

All analyzed economic cycles of Haiti on the chart lag significantly behind the world economy in development. The economy demonstrates progressive development in three periods (1969-75, 1994-2001, 2011-18), passing into regressive development (1976-85, 1986-93) and conservative (1960-68, 2002-10). There are no coincidences with the former metropolis, opposite trends 1 out of 6 .

The economy of Algeria shows a lag behind the world in the only regressive period of $1960-68$, which is replaced by a progressive one $(1969-75,1976-85)$ and goes over to the advanced development of the economy. Further, the growth of the national economy begins to lag behind the development of the world, which we observe presently. But nevertheless, the development proceeds according to the conservative scenario (1986-93), giving way to progressive periods (1994-2001, 2002-10), passing to the conservative one (2011-18). There is no coincidence with parent state and four opposite trends. 


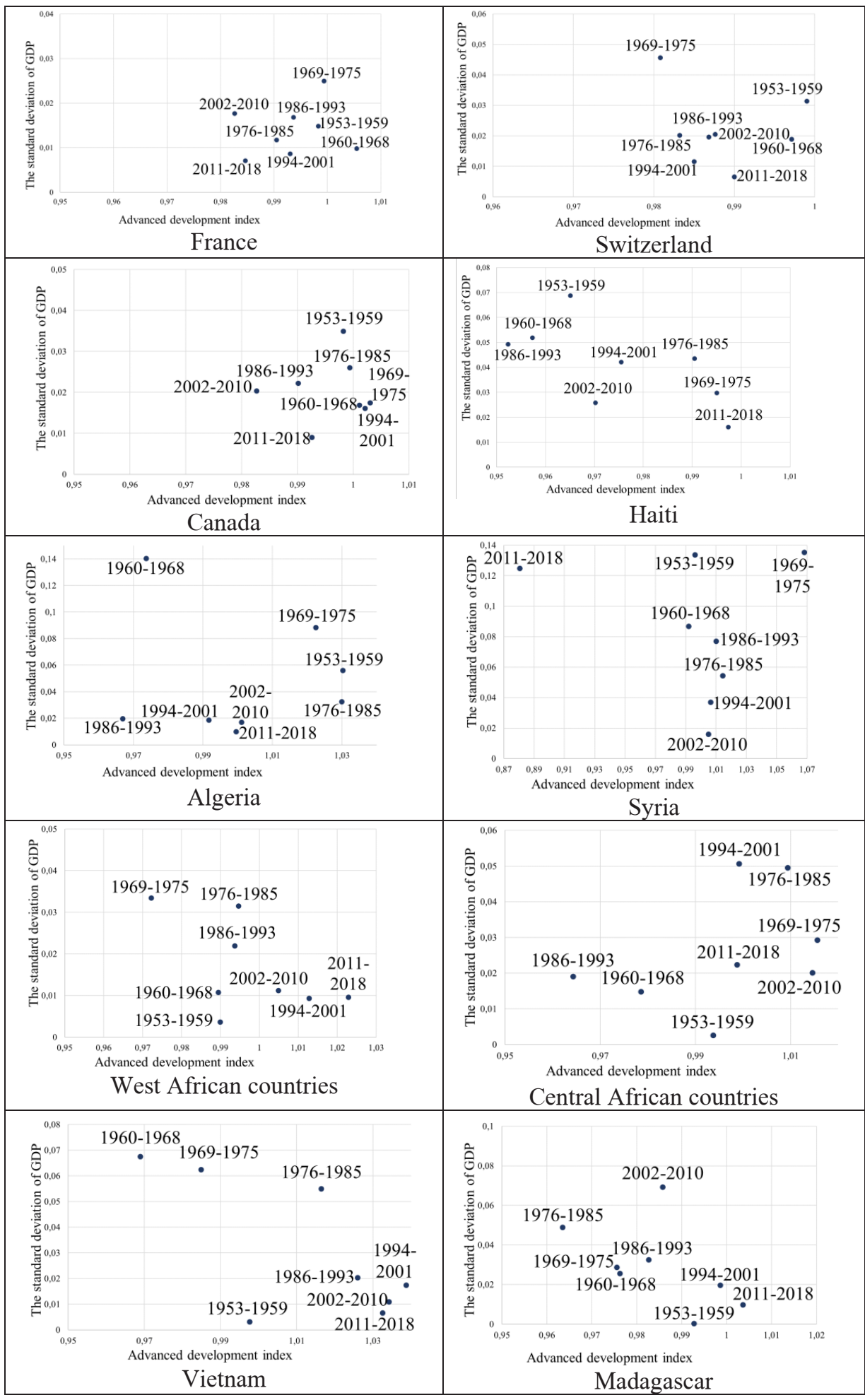

Fig. 1. Indicators of the economic development of the countries of the former French Empire. 
Syria in most periods demonstrates the outstripping development of the economy, which falls on the conservative scenario (1960-68, 1976-85, 1994-2001, 2002-10). The aggressive period falls on 1969-75, the regressive one occurs in 1986-93. The modern period of the regressive development of the economy (2011-18) falls on the war, a significant lag of the national economy from the world one occurs. There are two coincidences and one opposite trend.

For the countries of West Africa, during the regressive periods of 1960-68 and 1969-75, the economy lagged behind the world one. Further, the lag remains, but the development scenario changes to progressive in periods $(1976-85,2011-18)$ and conservative in periods (1986-93, 1994-2001). The regressive period also is apparent in 2002-10. In general, the modern period of development for African countries is the most successful; the economy has left behined world since the mid-90s, despite military and political conflicts, and is considered as a new pole of growth [5]. The ratio of coincidences and opposite trends is 2 to 1 .

The lagging behind the world economy of Central African countries falls on the regressive periods (1960-68, 2011-18) and conservative (1986-93). Aggressive periods (1969-75, 1994-2001) brought the national economy to the world level and ahead of the curve. The outstripping development also falls on the progressive period (2002-10) and regressive (1976-85). The ratio of coincidences and opposite trends is 0 to 4 .

Vietnam's economy has been showing rapid development since the $70 \mathrm{~s}$. The first period of regressive development falls on 1960-68, then there is an increase in the rate of economic development and progressive periods begin (1969-75, 1976-85, 1986-93, 19942001), which are replaced by conservative ones (2002-10, 2011-18 The ratio of coincidences and opposing trends is 0 to 2 .

The economy of Madagascar is in a lagging zone for the entire period of observation. Regressive periods (1960-68, 1969-75, 1976-85) were replaced by progressive ones (1986$93,1994-2001)$. Then again there is a regressive period (2002-10), which is replaced by a progressive one (2011-18). The ratio of coincidences and opposite trends is 2 to 1 .

Table 1. Dynamics of development of national economies of the countries of the former French Empire

\begin{tabular}{|c|c|c|c|c|c|c|}
\hline The country & $\begin{array}{l}1960- \\
1968\end{array}$ & $\begin{array}{l}1969- \\
1975\end{array}$ & $\begin{array}{l}1976- \\
1985\end{array}$ & $\begin{array}{l}1986- \\
1993\end{array}$ & $\begin{array}{l}1994- \\
2001\end{array}$ & $2002-2010$ \\
\hline France & $\begin{array}{l}\text { Outstr. } \\
\text { Progr. }\end{array}$ & $\begin{array}{l}\text { Lag. } \\
\text { Regres. }\end{array}$ & $\begin{array}{l}\text { Lag. } \\
\text { Cons. }\end{array}$ & $\begin{array}{l}\text { Lag. } \\
\text { Aggres. }\end{array}$ & $\begin{array}{l}\text { Lag. } \\
\text { Cons. }\end{array}$ & $\begin{array}{l}\text { Lag. } \\
\text { Regres. }\end{array}$ \\
\hline Switzerland & $\begin{array}{l}\text { Lag. } \\
\text { Cons. }\end{array}$ & $\begin{array}{l}\text { Lag. } \\
\text { Regres. }\end{array}$ & $\begin{array}{l}\text { Lag. } \\
\text { Progr. }\end{array}$ & $\begin{array}{l}\text { Lag. } \\
\text { Progr. }\end{array}$ & $\begin{array}{l}\text { Lag. } \\
\text { Cons. }\end{array}$ & $\begin{array}{l}\text { Lag. } \\
\text { Aggres. }\end{array}$ \\
\hline Canada & $\begin{array}{l}\text { Outstr. } \\
\text { Progr. }\end{array}$ & $\begin{array}{l}\text { Опер. } \\
\text { Агрес. }\end{array}$ & $\begin{array}{l}\text { Lag. } \\
\text { Regres. }\end{array}$ & $\begin{array}{l}\text { Lag. } \\
\text { Cons. }\end{array}$ & $\begin{array}{l}\text { Outstr. } \\
\text { Progr. }\end{array}$ & $\begin{array}{l}\text { Lag. } \\
\text { Regres. }\end{array}$ \\
\hline Haiti & $\begin{array}{l}\text { Lag. } \\
\text { Cons. }\end{array}$ & $\begin{array}{l}\text { Lag. } \\
\text { Progr. }\end{array}$ & $\begin{array}{l}\text { Lag. } \\
\text { Regres. }\end{array}$ & $\begin{array}{l}\text { Lag. } \\
\text { Regres. }\end{array}$ & $\begin{array}{l}\text { Lag. } \\
\text { Progr. }\end{array}$ & $\begin{array}{l}\text { Lag. } \\
\text { Cons. }\end{array}$ \\
\hline Algeria & $\begin{array}{l}\text { Lag. } \\
\text { Regres. }\end{array}$ & $\begin{array}{l}\text { Outstr. } \\
\text { Progr. }\end{array}$ & $\begin{array}{l}\text { Outstr. } \\
\text { Progr. }\end{array}$ & $\begin{array}{l}\text { Lag. } \\
\text { Cons. }\end{array}$ & $\begin{array}{l}\text { Lag. } \\
\text { Progr. }\end{array}$ & $\begin{array}{l}\text { Lag. } \\
\text { Progr.. }\end{array}$ \\
\hline Syria & $\begin{array}{l}\text { Lag. } \\
\text { Cons. }\end{array}$ & $\begin{array}{l}\text { Outstr. } \\
\text { Aggres. }\end{array}$ & $\begin{array}{l}\text { Outstr. } \\
\text { Cons. }\end{array}$ & $\begin{array}{l}\text { Outstr. } \\
\text { Regres. }\end{array}$ & $\begin{array}{l}\text { Outstr. } \\
\text { Cons. }\end{array}$ & $\begin{array}{l}\text { Outstr. } \\
\text { Cons. }\end{array}$ \\
\hline West Africa & $\begin{array}{l}\text { Lag. } \\
\text { Regres. }\end{array}$ & $\begin{array}{l}\text { Lag. } \\
\text { Regres. }\end{array}$ & $\begin{array}{l}\text { Lag. } \\
\text { Progr. }\end{array}$ & $\begin{array}{l}\text { Lag. } \\
\text { Cons. }\end{array}$ & $\begin{array}{l}\text { Outstr. } \\
\text { Progr. }\end{array}$ & $\begin{array}{l}\text { Outstr. } \\
\text { Regres. }\end{array}$ \\
\hline Central Africa & $\begin{array}{l}\text { Lag. } \\
\text { Regres. }\end{array}$ & $\begin{array}{l}\text { Опер. } \\
\text { Агрес. }\end{array}$ & $\begin{array}{l}\text { Outstr. } \\
\text { Regres. }\end{array}$ & $\begin{array}{l}\text { Lag. } \\
\text { Cons. }\end{array}$ & $\begin{array}{l}\text { Lag. } \\
\text { Aggres }\end{array}$ & $\begin{array}{l}\text { Outstr. } \\
\text { Progr. }\end{array}$ \\
\hline Vietnam & $\begin{array}{l}\text { Lag. } \\
\text { Regres. }\end{array}$ & $\begin{array}{l}\text { Lag. } \\
\text { Progr. }\end{array}$ & $\begin{array}{l}\text { Outstr. } \\
\text { Progr. }\end{array}$ & $\begin{array}{l}\text { Outstr. } \\
\text { Progr. }\end{array}$ & $\begin{array}{l}\text { Outstr. } \\
\text { Progr. }\end{array}$ & $\begin{array}{l}\text { Outstr. } \\
\text { Cons. }\end{array}$ \\
\hline Madagascar & $\begin{array}{l}\text { Lag. } \\
\text { Regres. }\end{array}$ & $\begin{array}{l}\text { Lag. } \\
\text { Regres. }\end{array}$ & $\begin{array}{l}\text { Lag. } \\
\text { Regres. }\end{array}$ & $\begin{array}{l}\text { Lag. } \\
\text { Progr. }\end{array}$ & $\begin{array}{l}\text { Lag. } \\
\text { Progr. }\end{array}$ & $\begin{array}{l}\text { Lag. } \\
\text { Regres. }\end{array}$ \\
\hline
\end{tabular}


By the coincidence of competitiveness (outstripping or lagging development), Switzerland, Haiti and Madagascar are leading with France - 5 periods out of 6, Canada and Algeria have 4 each, continental African countries - 3 each, Vietnam - 1 and Syria - 0 (see table. 2).

In calculating the index of proximity to historical fate, the weight of politics is 2 times higher than that of coincidences of advancing and lagging development due to the fact that the diversity of policies is 2 times higher. The index itself is the sum of the doubled difference between the coincidences of policies and the number of opposite development policies and the number of coincidences of advancing or lagging development referred to the number of periods studied (in our case, there are 6 of them). The maximum value of the historical fate index is $300 \%$; the similarity of the historical fate can be said approximately from the index value of $100 \%$, since a random match gives $50 \%$.

Table 2. Analysis of the coincidences and differences in the development of the economies of the countries of the former French Empire with the development of the French economy

\begin{tabular}{|c|c|c|c|c|c|}
\hline Countries & $\begin{array}{l}\text { Number of } \\
\text { coincidences } \\
\text { of advancing } \\
\text { or lagging } \\
\text { development }\end{array}$ & $\begin{array}{c}\text { Number of } \\
\text { coincidences } \\
\text { of economic } \\
\text { development } \\
\text { policies }\end{array}$ & $\begin{array}{l}\text { The number } \\
\text { of opposite } \\
\text { policies of } \\
\text { economic } \\
\text { development }\end{array}$ & $\begin{array}{l}\text { The } \\
\text { number of } \\
\text { points of } \\
\text { proximity } \\
\text { to historical } \\
\text { fate }\end{array}$ & $\begin{array}{l}\text { The index of } \\
\text { the proximity } \\
\text { of historical } \\
\text { fate, in\% of } \\
\text { the ratio of } \\
\text { the number of } \\
\text { points to the } \\
\text { number of } \\
\text { periods } \\
\text { studied }\end{array}$ \\
\hline Switzerland & 5 & 2 & 1 & $\begin{array}{c}2 \times(2- \\
1)+5=7\end{array}$ & 117 \\
\hline Canada & 4 & 2 & 1 & $\begin{array}{c}2 \times(2- \\
1)+4=6\end{array}$ & 100 \\
\hline Haiti & 5 & 0 & 1 & $\begin{array}{c}2 \times(0- \\
1)+5=3\end{array}$ & 50 \\
\hline Algeria & 4 & 0 & 4 & $\begin{array}{c}2 \times(0- \\
4)+4=4\end{array}$ & 67 \\
\hline Syria & 0 & 2 & 1 & $\begin{array}{c}2 \times(2- \\
1)+0=2\end{array}$ & 33 \\
\hline West Africa & 3 & 2 & 1 & $\begin{array}{c}2 \times(2- \\
1)+3=5\end{array}$ & 83 \\
\hline Central Africa & 3 & 0 & 4 & $\begin{array}{c}2 \times(0-4)+3= \\
-5\end{array}$ & -83 \\
\hline Vietnam & 1 & 0 & 2 & $\begin{array}{c}2 \times(0-2)+3= \\
-1\end{array}$ & -17 \\
\hline Madagascar & 5 & 2 & 1 & $\begin{array}{c}2 \times(2- \\
1)+5=7\end{array}$ & 117 \\
\hline
\end{tabular}

\section{Conclusions}

Thus, Switzerland and Madagascar have the most overlaps in competitiveness and development policy compared to France. Canada is slightly inferior to them only by coincidences in competitiveness. West Africa has the same overlap in politics, but less (on a random level) in competitiveness. Haiti, on the other hand, has the same competitiveness but no development policy overlaps. Algeria and Central Africa usually have opposite 
policies, Syria and Vietnam show the opposite in terms of competitiveness. On the whole, this confirms our hypothesis about the similarity in the development of the most culturally close countries.

If the similarity of the economic development of the Black African countries with France occurs due to the underdevelopment and dependence of their economies on relations with the former metropolis, then only those countries (Syria and Vietnam) that have formed their own institutional systems that are significantly different from the former metropolis demonstrate stable advanced development. Algeria, after gaining independence, had a leap in development, but faced the problem of the Dutch disease syndrome.

In general, it is fashionable to say with confidence that the French civilization, united by a common historical destiny, did not arise on the territory of the former French Empire. France is a part of Western civilization, with the countries of which it has the greatest similarity in competitiveness and development policy, and its former African and Asian colonies are developing independently, in accordance with the historical fate of their civilizations.

This study can be considered as evidence of the need to develop a model of a multipolar world, in which it is necessary to introduce the statistically proven influence of culture on economic development and the need to form institutions of economic development that are authentic to each culture, without which the competitiveness and advanced development of countries trying to maintain independence from the global West are unattainable. Solutions to the problem of the formation of institutions of economic development that are authentic to culture have been proposed by the authors in a number of works $[1,17,18]$, incl. for Russian culture, among which one can single out the institutions of domination of consumer ownership of enterprises and means of production, institutions of direct democracy, institutions that exclude the opportunism of investors, workers and managers.

\section{Acknowledgements}

The reported study was funded by RFBR, project number 20-010-00869.

\section{References}

1. M. Yu. Savelyev, Multicultural institutionalism: General economic theory of civilizations. The political economy of traditionalism. Network Society Project, 488 (2015)

2. M. Yu. Savelyev, Bulletin of the Udmurt University, Series "Economics and Law", 7, 76 (2015)

3. M. Yu. Savelyev, Bulletin of the Udmurt University, Series "Economics and Law", 7, 135 (2015)

4. M. Yu. Savelyev, Natalia Pushina, Andrey Savchenko, E3S Web Conf., 208, 03052 (2020) https://www.e3s-conferences.org/

5. I.O. Abramova, Africa in the Modern Model of the World Order: a Powerful Player or an Outsider? Outlines of global transformations: politics, economics, law, 11(5), 6 (2018)

6. A.Z. Manfred, History of France, 3 (1973)

7. J.-Ch. Aslan, Economic history of France from the eighteenth century to the present day (1995)

8. F.Y. Polyanskiy, V.A. Jamin, Economic history of capitalist countries (1986) 
9. Ivan T. Berend, An Economic History of Twentieth-Century Europe: Economic Regimes from Laissez-Faire to Globalization, 368 (2016)

10. A.G. Khudokormov, World of the New Economy, 13(2), 55 (2019)

11. A.S. Bikkulov, M.G. Salazkin, Foresight in Canada: two levels. Foresight, 1(2), 68 (2007)

12. L.A. Nemova, Canadian Yearbook, 20 (2016)

13. Angus Maddison Historical Statistics, http://www.ggdc.net/

14. J. Bolt, J.L. van Zanden, Economic History Review, 67(3), 627 (2014)

15. Total economy database (TED), https://www.conference-board.org/

16. World Bank, "World Development Indicators", https://databank.worldbank.org/

17. M. Yu. Savelyev, Bulletin of the Udmurt University, Series "Economics and Law", 5, 58 (2016)

18. M. Yu. Savelyev, Science of Udmurtia, 3(77), 47 (2016) 